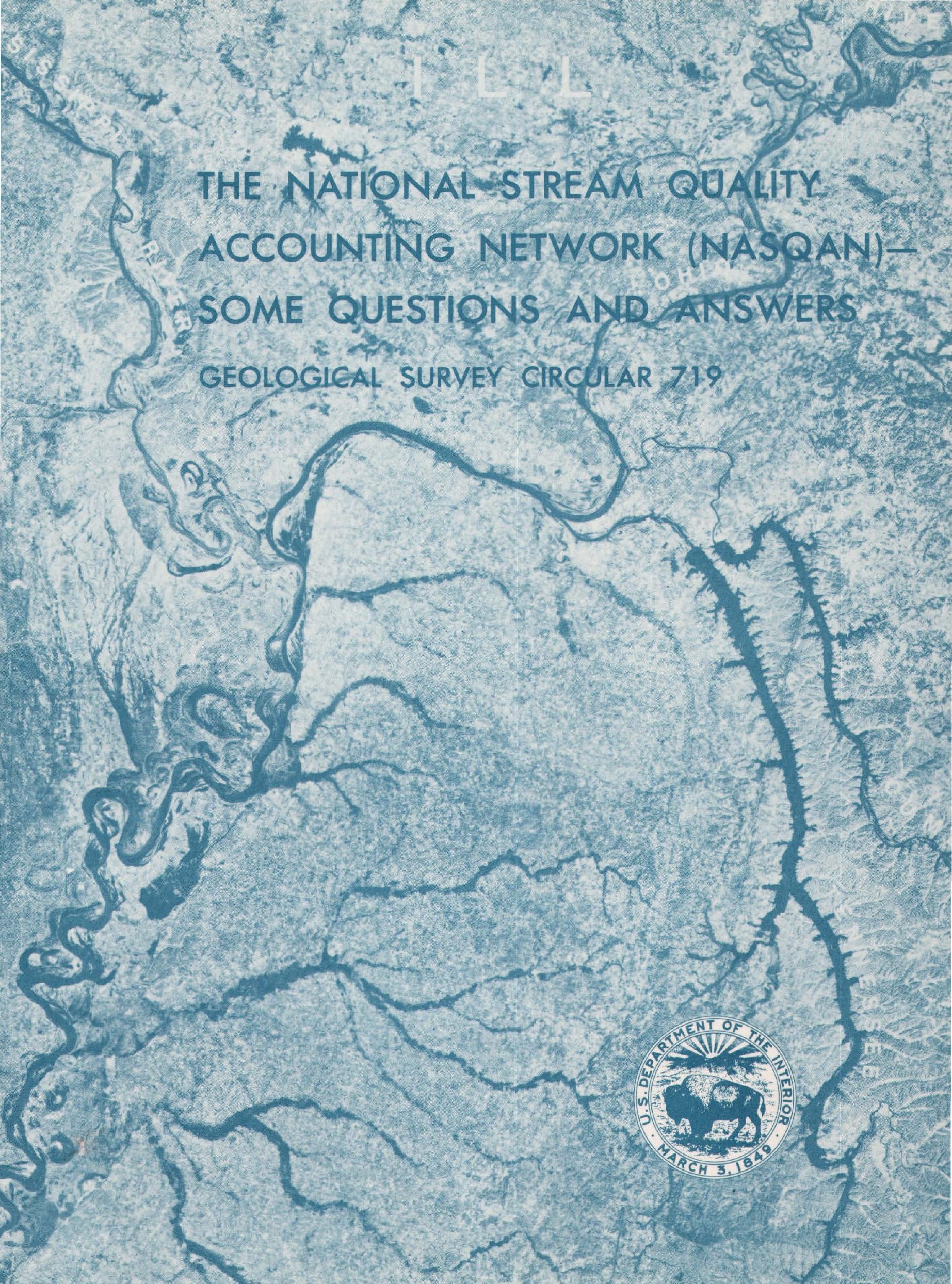





\title{
THE NATIONAL STREAM QUALITY ACCOUNTING NETWORK (NASQAN)- SOME QUESTIONS AND ANSWERS
}

\author{
By John F. Ficke and Richard O. Hawkinson
}

GEOLOGICAL SURVEY CIRCULAR 719 


\section{United States Department of the Interior}

STANLEY K. HATHAWAY, Secretary

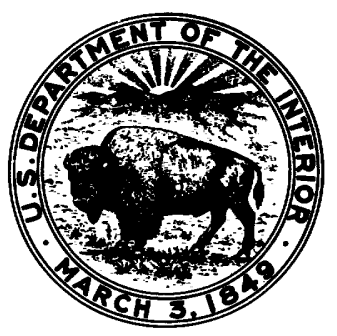

\section{Geological Survey \\ V. E. McKelvey, Director}

\section{Library of Congress Cataloging in Publication Data}

Ficke, John F

The National Stream Quality Accounting Network (NASQAN) - Some questions and answers.

(Geological Survey circular ; )

Bibliography: p.

Supt. of Docs. no.: I 19.4/2:

1. Water quality management-United States. 2. Water-Pollution-United States-Measurement. 3. National Stream Quality Accounting Network. I. Hawkinson, Richard O., joint author. II. Title. III. Series: United States. Geological Survey. Circular ;

QE75.C5 [TD223] 557.3'08s [628.1'61'0973] 75-619140 


\section{CONTENTS}

Introduction

Purpose

What is NASQAN?

Why is it needed?

How are NASQAN stations different from those that have operated for many years?

Who began NASQAN?

Accounting networks

What are the geographical units used in level I accounting?

How are NASQAN stations located within accounting units?

How are stations in coastal units selected?

How are sites selected for stations in closed basins?
Page

1 Operation

1

1

1

2

2

3

3

3

5

5

5

How many stations are in NASQAN and where are they? -

What water-quality characteristics are measured at NASQAN stations?

Will changes be made in the suite of chara:teristics measured at NASQAN stations? --

Who collects data at NASQAN stations? -...-

How long will stations be operated?

What will be done with the data?

What will be the principal problems in tl? interpretation of the data?

What is the policy regarding NASQAN stations near reservoirs?

Summary _-

5

Page
8
8
8

8
8
10
11

12
12
12
12

Page

8

8

8

8

8

10

11

\section{ILLUSTRATIONS}

Cover Mosaic of ERTS imagery showing parts of the Tennessee, Ohio, and Mississippi Rivers. Uncontrolled mosaic from photo prints of band 6 ERTS multispectral scanner data, constructed by the Maps and Surveys Branch of the Tennessee Valley Authority.

FIGURE 1. Map of United States showing outlines of regions and accounting units

2. Map showing accounting units in New England _........- 6

3. Map of United States showing NASQAN stations in operation January 1, 1975

4. Graph showing numbers of stations in NASQAN, 1973-78 10

\section{TABLE}

TABLE 1. Stations in the National Stream Quality Accounting Network on 


\title{
The National Stream Quality Accounting Nefwork (NASQAN)- Some Questions and Answers
}

\author{
BY JOHN F. FICKE and RICHARD O. HAWKINSON
}

\section{INTRODUCTION}

One of the major new efforts of the U.S. Geological Survey is the National Stream Quality Accounting Network (NASQAN). This circular is intended to answer some of the frequently asked questions concerning concepts used in establishing NASQAN, its purposes, design, value, and future plans.

\section{PURPOSE}

\section{What is NASQAN?}

NASQAN is a series of stations at which systematic and continuing measurements are made to determine the quality of the Nation's streams. Design of the network specifies measurement of a broad range of water-quality characteristics which were selected to meet many of the information requests of groups involved in planning and management on a national or regional scale. The primary objectives are (1) to account for the quantity and quality of water moving within and from the United States, (2) to depict areal variability, (3) to detect changes in stream quality, and (4) to lay the groundwork for future assessments of changes in stream quality.

\section{Why is it needed?}

Data of the type needed to determine longterm trends in the physical, chemical, and biological characteristics of the Nation's surface waters are relatively sparse. Wolman (1971) and Enviro Control (1972) have documented the problems associated with the assessment of changes in characteristics of surface waters. Wolman stated some fairly obvious problems involving statistical analysis of water-quality data; these include (1) the relatively short length of hydrologic records, (2) changes in location and frequency of observations, (3) the fact that comparisons of specific variables related to surface-water quality require systematic correlation with hydrologic behavior, and (4) the fact that knowledge of temporal variability of a specific constituent is often essential to the detection of a trend. Enviro Control's study verified the existence of the first problem, noting that of 70,000 stations in the Environmental Protection Agency's waterquality data-storage system, only 142 stations had 8 or more years of records of samples taken as frequently as at quarterly intervals.

Another problem is the unbalanced areal distribution of existing stations having adequate data for statistical analysis. Seventy percent of the stations used in the Enviro Control study were in the northwestern and northeastern United States. Steele and others (1974) noted a deficiency of stations in the northcentral and southeast United States. With continued operation of the series of stations established under NASQAN, a set of systematically collected baseline water-quality data will be available for nationwide studies involving transport of and changes in chemical constituents in surface waters.

NASQAN also will provide data needed to assess regional trends in order to evaluate the 
effectiveness of programs to control water quality. Such assessments will provide local and State officials with some of the information required to judge whether revisions in programs or new legislation is needed. However, the broad-scale information from NASQAN is not likely to be detailed enough to assess the effectiveness of pollution-control measures on a localized basis, as prescribed by Public Law 92-500. Enough insight should be supplied by the NASQAN data, however, to identify problem areas which require detailed monitoring of subbasins to evaluate the effects of land use and treatment measures.

\section{How are NASQAN stations different from those that have operated for many years?}

Stations in NASQAN are different in that they form a nationwide network in which station location was based upon hydrologic subdivision of river basins. This assures fairly uniform coverage of the entire United States, including Puerto Rico. NASQAN stations can be further characterized by the facts that a uniform operational design has been designated and station operations are committed to fulfilling the long-term objectives of detection of trends in water quality.

In the past, it has not been possible, on a nationwide basis, to determine areal differences and (or) changes in water quality over time because most data-collection programs have been operated to satisfy local objectives or objectives of special programs. Consequently, the stations have been operated for short periods, have been moved frequently, and have experienced variation in constituents sampled. However, it should be noted that many of the stations specified in NASQAN were previously operated for other programs and that some historical data exist for certain chemical constituents (primarily the common constituents) that will be useful in evaluation of trends. Unfortunately, most previous data-collection programs did not monitor the suites of constituents (nitrogen and phosphorus species, bacteria, minor elements, organic indicators, and biological parameters) that are of primary concern in establishing the suitability of water for a given use. The NASQAN program, as designed, will help to eliminate this deficiency as well as, in time, some of the problems which Wolman

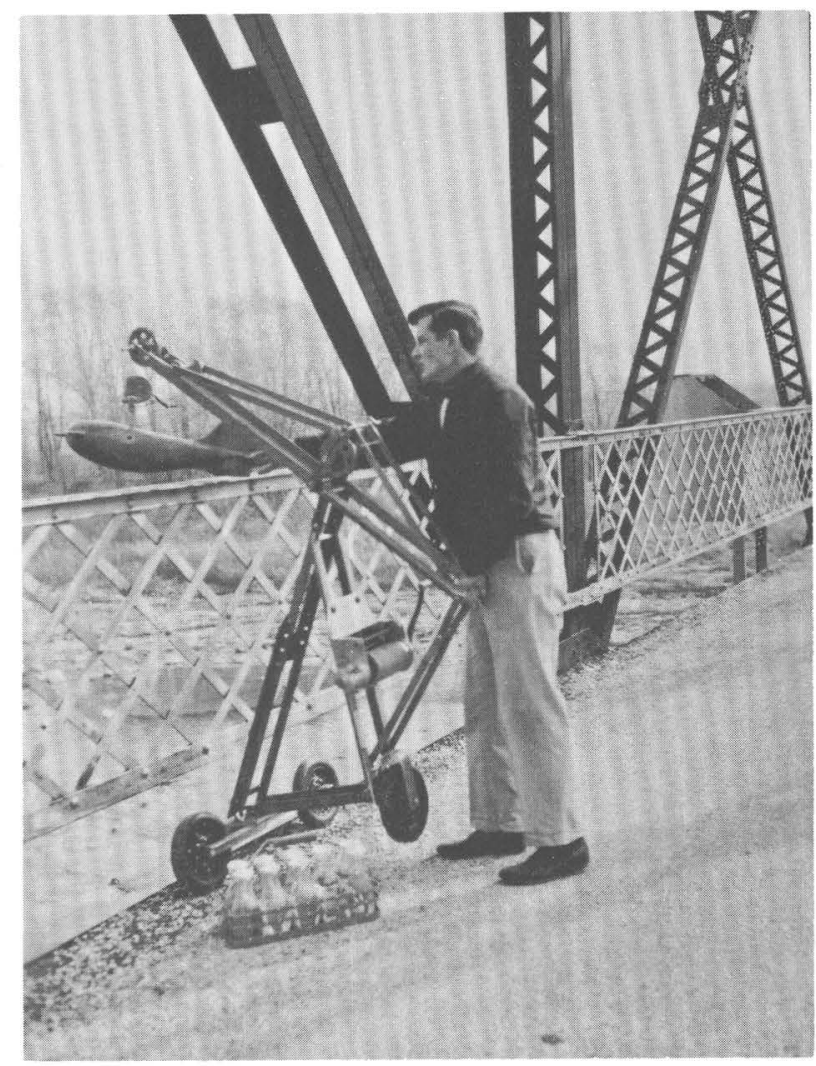

Sampling from bridge.

(1971) discussed; notably, establishing the data base needed for nationwide evaluation of trends in quality of surface waters, and the need to account for the movement of materials in surface waters.

In addition, NASQAN will use other agencies' documentation of the man-induced changes that occur within basins to help explain changes that may occur in water quality. Water-quality data from adjacent nonnetwork stations and other environmental data will also be used in the analyses and interpretation of NASQAN data, particularly where changes in the waterquality characteristics of a river are detected.

\section{Who began NASQAN?}

NASQAN was established by the U.S. Department of Interior, Geological Survey. The initial need for a national network to provide water data for Federal agencies was recognized in Bureau of the Budget Circular A-67, dated August 28, 1964. The circular stated that the national network is the mechanism for providing data on the quantity and quality of surface water and ground water, including sedi- 


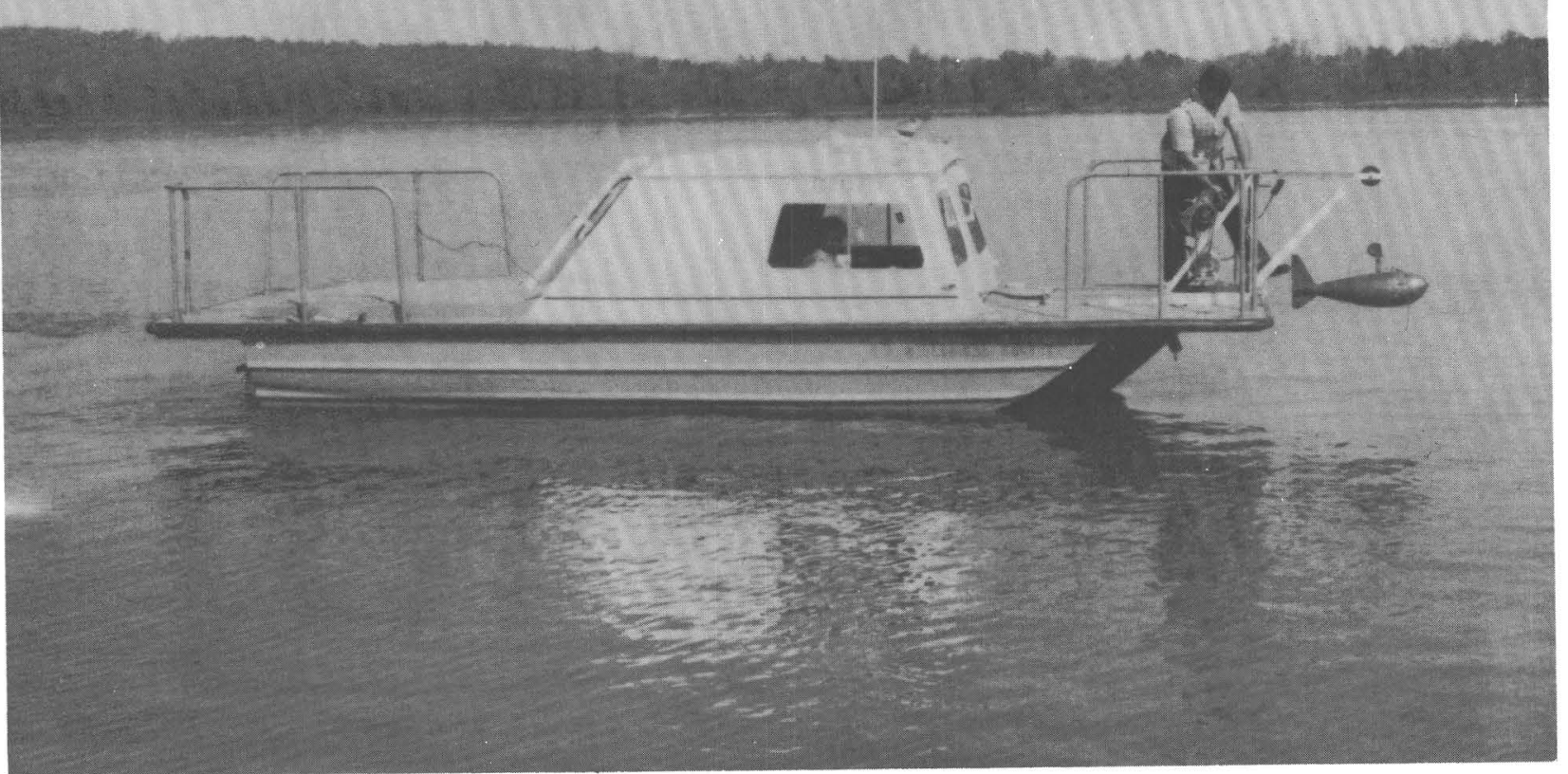

Sampling by boat in a large river.

ment load of streams, and it assigns the responsibility for network operation to the Department of the Interior. The Office of Water Data Coordination of the U.S. Geological Survey was designated by the Secretary of the Interior to design and coordinate the National Water Data Network.

As a basis for network design activities, the Office of Water Data Coordination used the "level-of-information concept" to specify three categories (levels I, II, and III) into which data-collection activities can be classified (Langford and Davis, 1970). Level I data constitute a basic level of information nationwide and thus are suitable for broad national and regional planning and as a foundation for more detailed work in the future.

The need for a national river-quality accounting network to provide broad-scale accounting data (Office of Water Data Coordination level I information) was a primary component of a Departmental "thrust document" on river-quality monitoring in March 1972. On the basis of this impetus, NASQAN became an official activity of the Geological Survey.
Data-collection activities were either initiated or upgraded at 50 stations in January 1973, and at another 50 stations in January 1974 , to meet the design specifications for network operation. Appropriations during the 1975 fiscal year permitted expansion to at least one station in each unit of the level I accounting network, thereby placing the present level of network operations at 345 stations.

\section{ACCOUNTING NETWORKS}

What are the geographical units used in level I accounting?

Through the Water Resources Planning Act of 1965 (PL 89-80), the Water Resources Council was established to provide a framework that would facilitate coordination of water-resource and land-resource activities. In compliance with this charge, Water Resources Council (1970) divided the United States into waterplanning regions and subregions. The U.S. Geological Survey's Office of Water Data Coordination has carried the division one step further by specification of accounting units. Figure 1 outlines the existing 21 regions and 324 accounting units in the United States. 


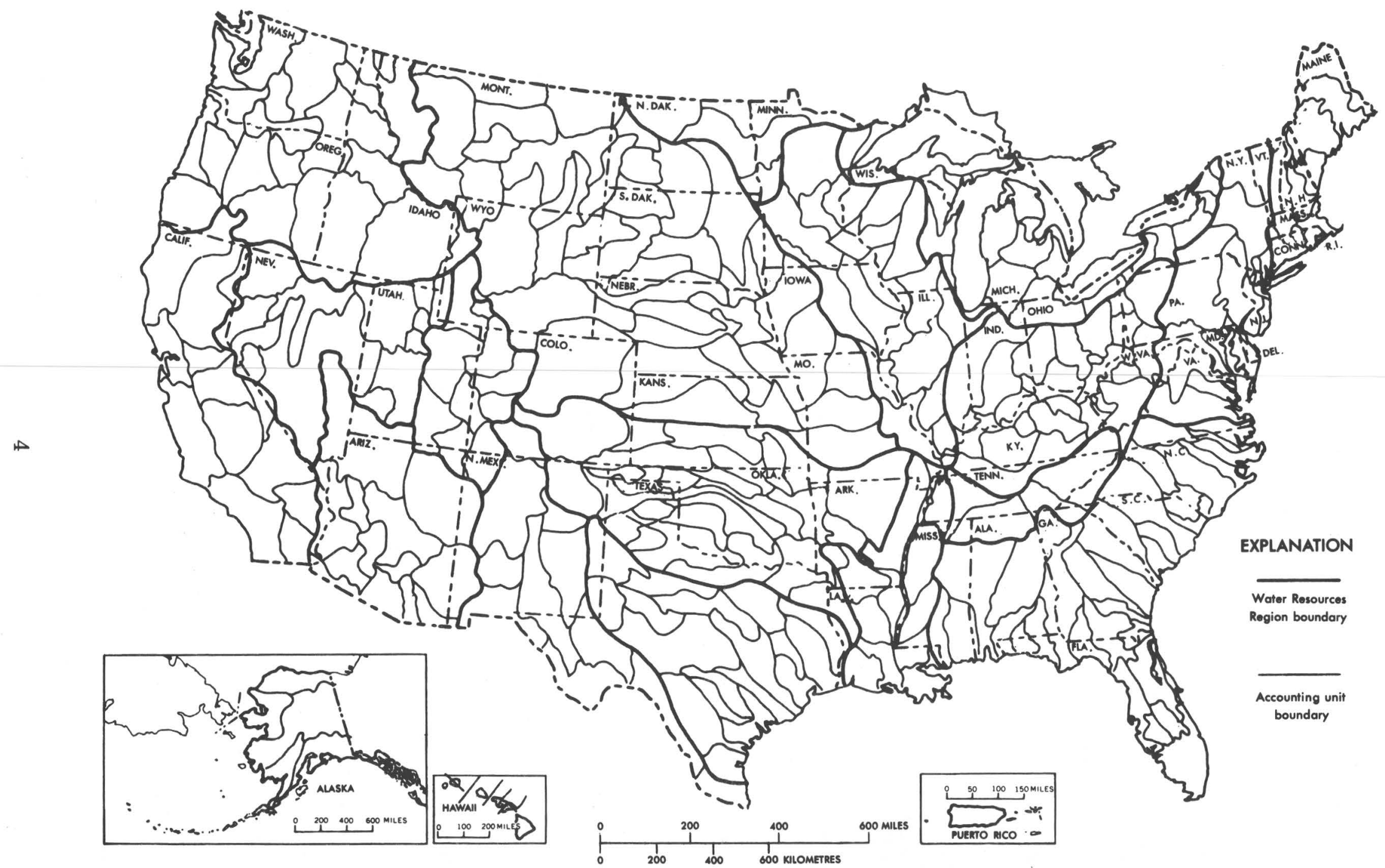

FIGURE 1.-Outlines of the 21 regions and the 324 accounting units as defined by the U.S. Water Resources Council and the Office of Water Data Coordination (U.S. Department of Interior, Geological Survey). 
The Office of Water Data Coordination is presently revising certain accounting-unit boundaries, using input from other Federal, State, and local agencies. Revisions receive approval from the Water Resources Council before publication of base maps (Hydrologic Unit Map -1974, U.S. Geological Survey, issued by State) bearing the hydrologic subdivisions.

Accounting units in New England are shown at a larger scale $(1: 5,000,000)$ in figure 2 to illustrate in greater detail than in figure 1 how stream drainage patterns influence selection of station locations. Figure 2 shows that accounting units along coastlines are drained by numerous streams flowing into the sea; similar situations exist along the shores of the Great Lakes. In inland accounting units, however, most of the outflow drains by single streams.

How are NASQAN stations located within accounting units?

Guidelines for level I accounting that have been established specify that data will measure water discharge and water quality for approximately 90 percent of the surface water leaving an accounting unit. This means that most NASQAN stations will measure or account for discharge and quality at a stream station near the downstream end of each accounting unit. Obvious exceptions must be made for units that discharge to the oceans or to the Great Lakes, across international boundaries, or into closed basins. Current revisions of accounting-unit boundaries have been reviewed and apparently have little affect on the locations of stations specified in 1972 for inclusion in the network.

\section{How are stations in coastal units selected?}

As figure 2 shows, some units stretch along coastlines (oceans or the Great Lakes) where numerous stations would be needed to sample 90 percent of the flow. This problem has been recognized in the design of NASQAN, and special criteria have been established for selecting station locations within coastal accounting units. NASQAN stations have been located to provide a sampling of from 30 to 50 percent of the water flowing from the coastal accounting unit. Such sampling is possible because adjacent drainage basins usually have similar physio-

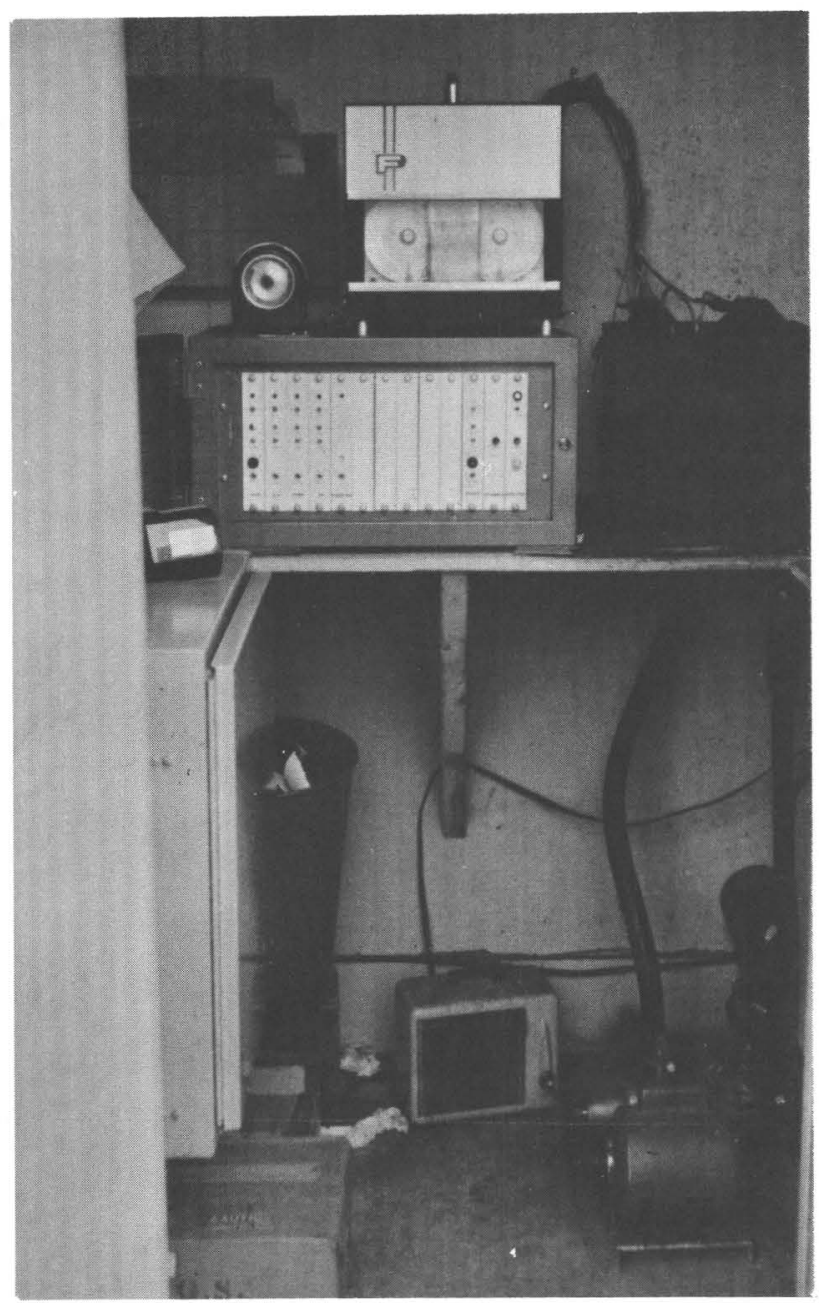

Automatic continuous monitor.

graphic and hydrologic characteristics. Therefore, it may reasonably be inferred that waterquality data from properly selected stations may be extrapolated to represent the remainder of the discharge. In choosing sites for stations, short-term reconnaissance studies are needed to confirm similarity of waters. It is also necessary to recognize and evaluate obvious differences in such parameters as population patterns, geology, or industrial development.

\section{How are sites selected for stations in closed basins?}

Accounting units with only interior drainage have been considered on a case-by-case basis in the selection of NASQAN station locations. The principal policy has been to select sites on streams that represent as much of the drainage area of or flow within the accounting unit as possible. 


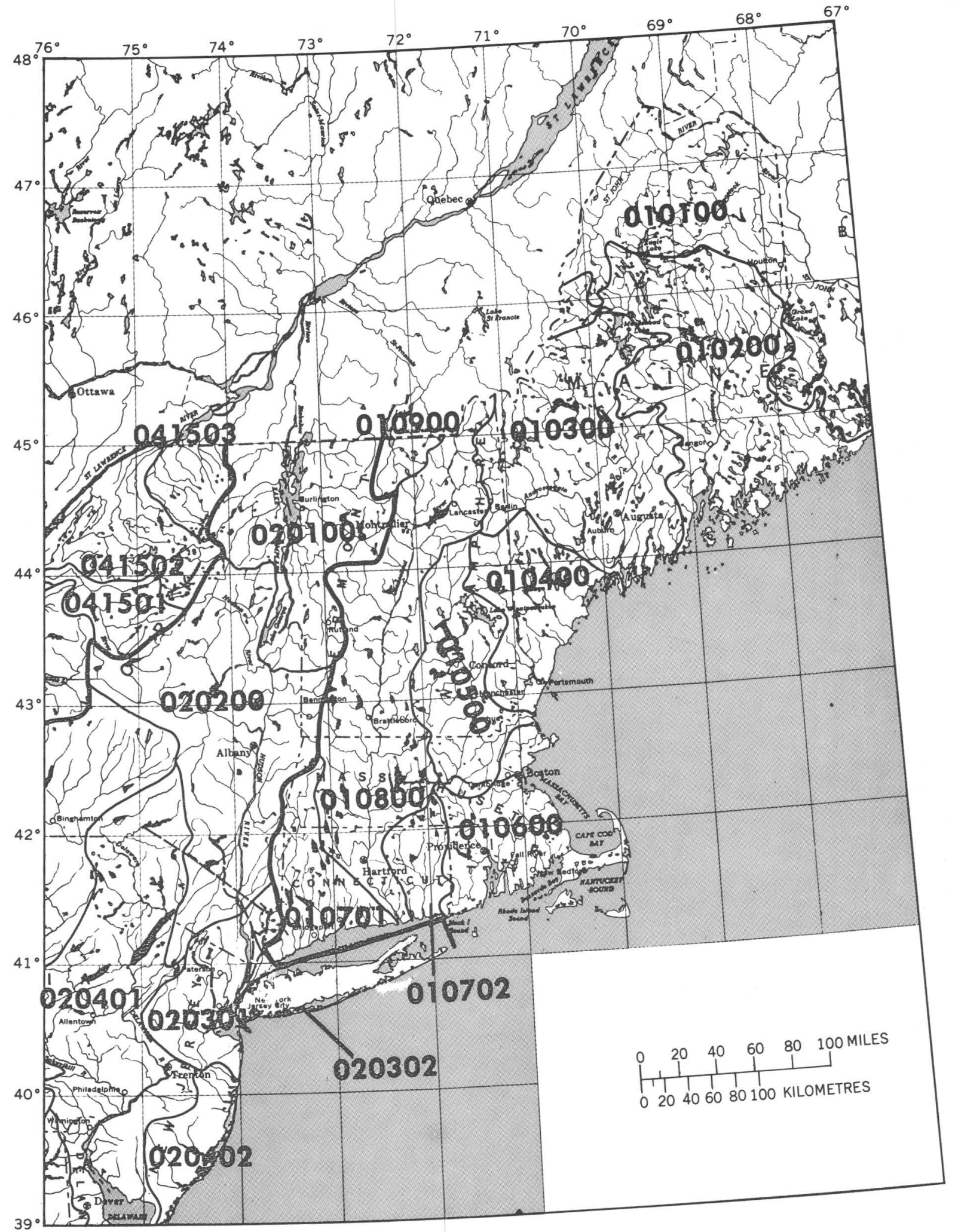

Figure 2.-Accounting units in New England. 

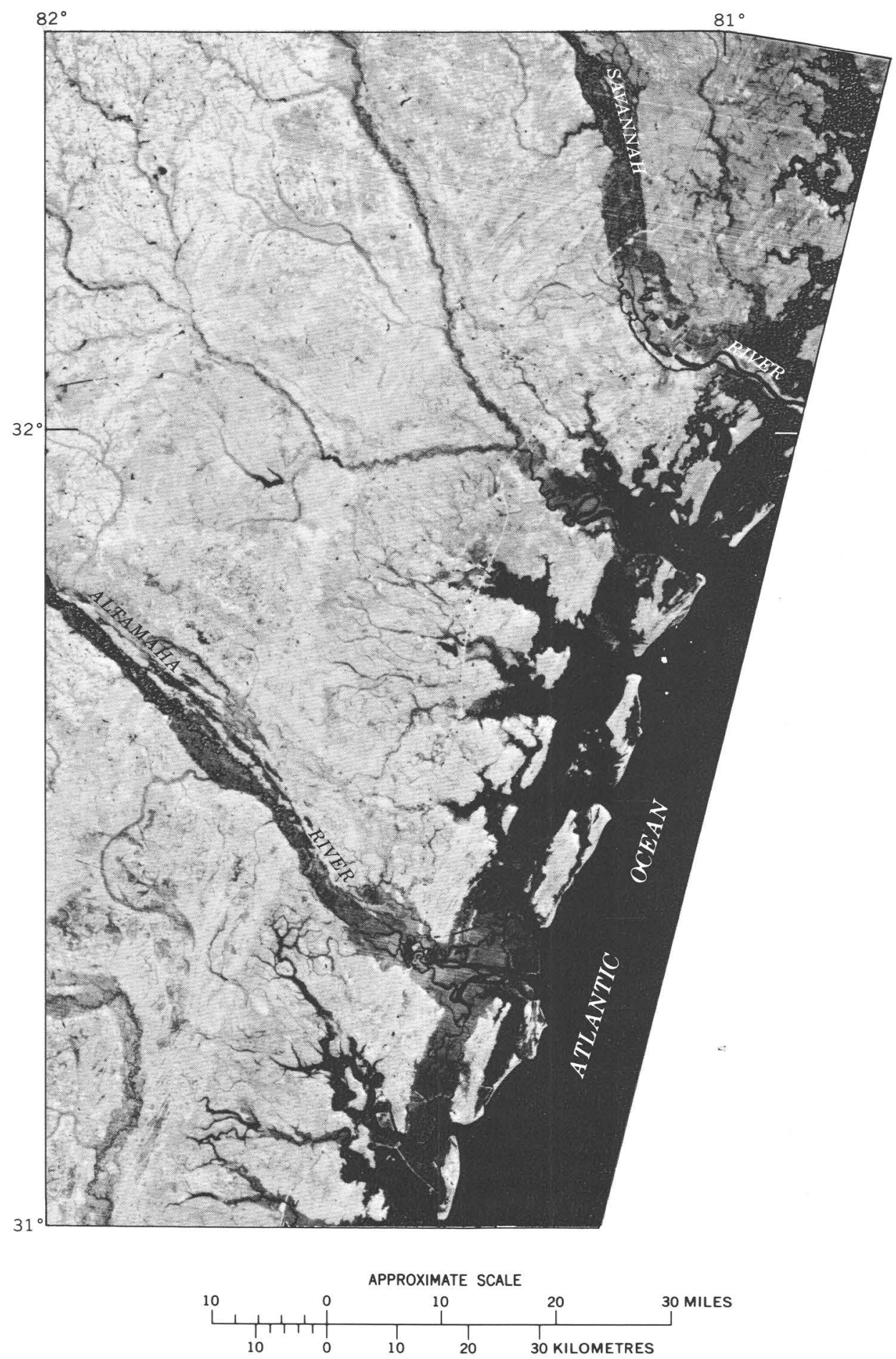

Part of the coast of Georgia from ERTS imagery, February 1974. (NASA ERTS E-1568-15284, band 7.) 


\section{OPERATION}

How many stations are in NASQAN and where are they?

As of January 1, 1975, 345 NASQAN stations were being operated. As stated earlier, the plan used in selecting locations of existing and future stations calls for most of them to be near the points of outflow from accounting units. Locations of the current 345 stations are shown in figure 3. Details of station location, including the names of towns or other cultural features near the stations, and latitudes and longitudes are given in table 1 (see p. 15).

Plans call for NASQAN to reach its final design size of 525 stations by October 1976. Figure 4 summarizes the network's past growth as well as the projected expansion to full implementation.

\section{What water-quality characteristics are measured at} NASQAN stations?

The following list summarizes the characteristics measured at network stations and the minimum frequencies of measurements under present network design.

Characteristics measured at NASQAN stations

[Frequencies: C, continuous; D, daily; M, monthly; Q, quarterly]

Field determinations:

Water temperature

Frequency

Specific conductance

pH

Discharge

$\mathrm{C}, \mathrm{D}$, or $\mathrm{M}$

${ }^{1} \mathrm{C}, \mathrm{D}$, or $\mathrm{M}$

Coliform, fecal M

Streptococci, fecal

C

M

$\mathrm{M}$

Common constituents (dissolved) ${ }^{2}$ :

(Bicarbonate, carbonate, total hardness, non-carbonate hardness, calcium, magnesium, fluoride, sodium, potassium, dissolved solids, silica, turbidity, chloride, and sulfate).

Major nutrients:

Phosphorus, total ${ }^{4}$ as $\mathbf{P}$

M

Nitrite plus nitrate, total as $\mathrm{N}$

Nitrogen, total Kjeldahl as $\mathbf{N}$

Trace elements (total and dissolved) :

(Arsenic, cadmium, chromium, cobalt, copper, iron, lead, manganese, mercury, selenium, and zinc).

Organics and biological:

Organic carbon, total

Phytoplankton, total, cells/ml

Phytoplankton, identification of $\mathbf{3}$ co-dominants
Characteristics measured at NASQAN stations-Con.

Organics and biological-Continued

Phytoplankton, 3 co-dominants, percent of total

Periphyton, biomass, dry weight $\mathbf{g} / \mathrm{m}^{2}$ -

Periphyton, biomass, ash weight $\mathrm{g} / \mathrm{m}^{2}$ -

Periphyton, chlorophyll $a$

Periphyton, chlorophyll $b$

Suspended sediment:

Suspended sediment concentration _-.- M

Percent finer than $0.062-\mathrm{mm}$ sieve diameter

${ }^{1}$ Continuous or daily depending upon whether the station is equipped with a monitor or whether daily observations are made. Monthly measurements made at stations where a long-term record is available.

2 Dissolved constituents in water are those remaining after filtering samples through 0.45 -micrometre membrane filters.

${ }^{3}$ Quarterly or monthly, depending upon whether relationships have been established between conductance and concentrations of various common constituents.

4 Total concentrations are those determined by analyses of unfiltered samples. They include both dissolved and suspended materials.

In addition to the measurements shown above, determinations of pesticide residues and radiochemical constituents are made at selected stations. These stations can be viewed as subnetworks of NASQAN.

\section{Will changes be made in the suite of characteristics measured at NASQAN stations?}

Yes, but in a manner that conforms with the stated objectives of the network. A continual examination will be made for correlations among measured characteristics. If correlations are established so that changes in one characteristic can be used to estimate changes in others, certain measurements may be discontinued. Also, some measurements may be added as water-quality characteristics change in importance. Consideration presently is being given to including two 24-hour dissolved oxygen profiles each year, to be conducted during critical periods; to monthly determination of ammonia nitrogen; and to an increased frequency of determination of total organic carbon, from quarterly to monthly. Any such adjustments in the operational design of the network will be made to coincide with the beginning of a water year (October 1).

\section{Who collects data at NASQAN stations?}

Most of the NASQAN data are and will be collected by the Geological Survey. However, 


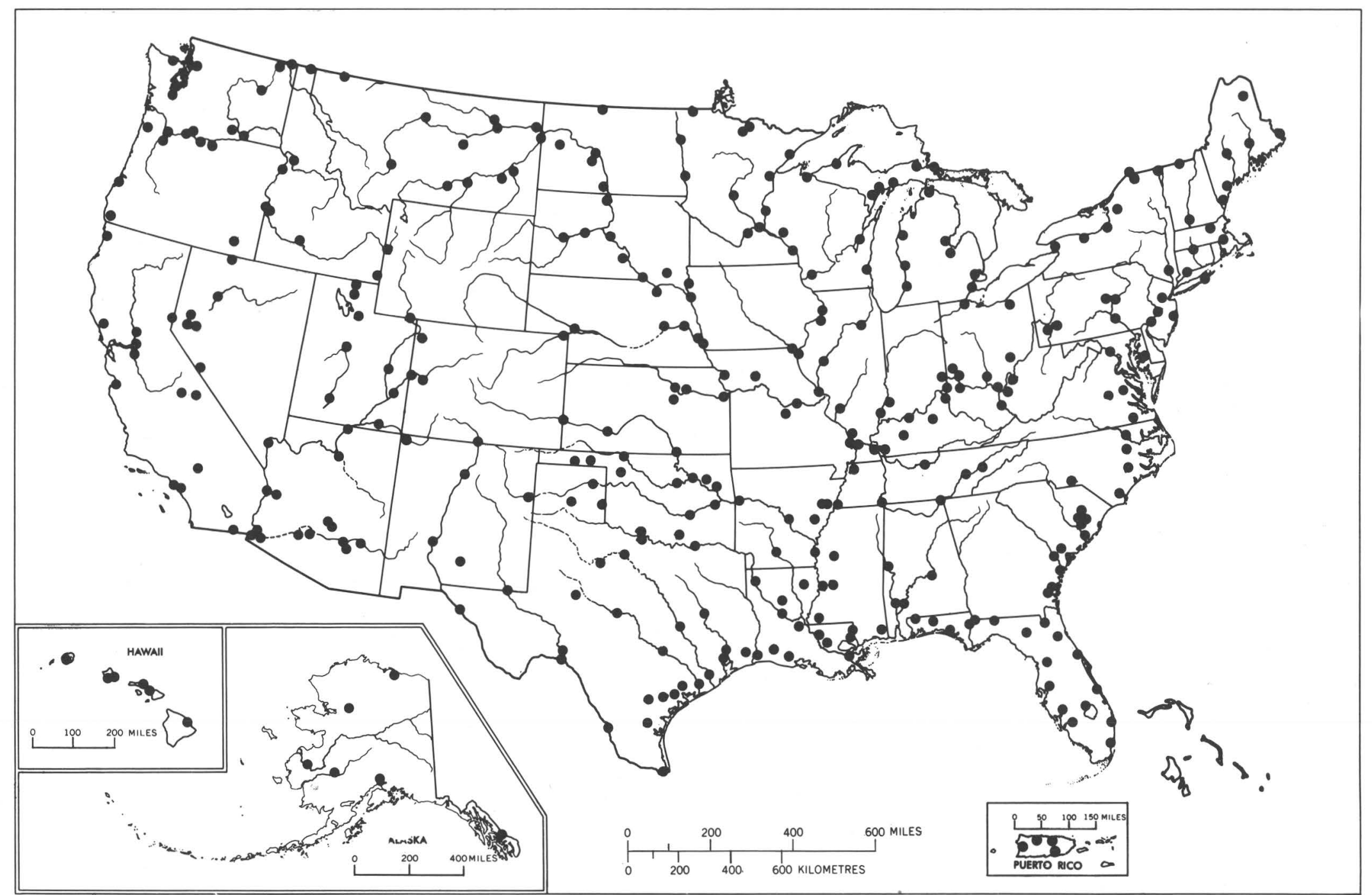

FIGURE 3.-Locations of stations in the National Stream Quality Accounting Network in operation as of January 1, 1975. 


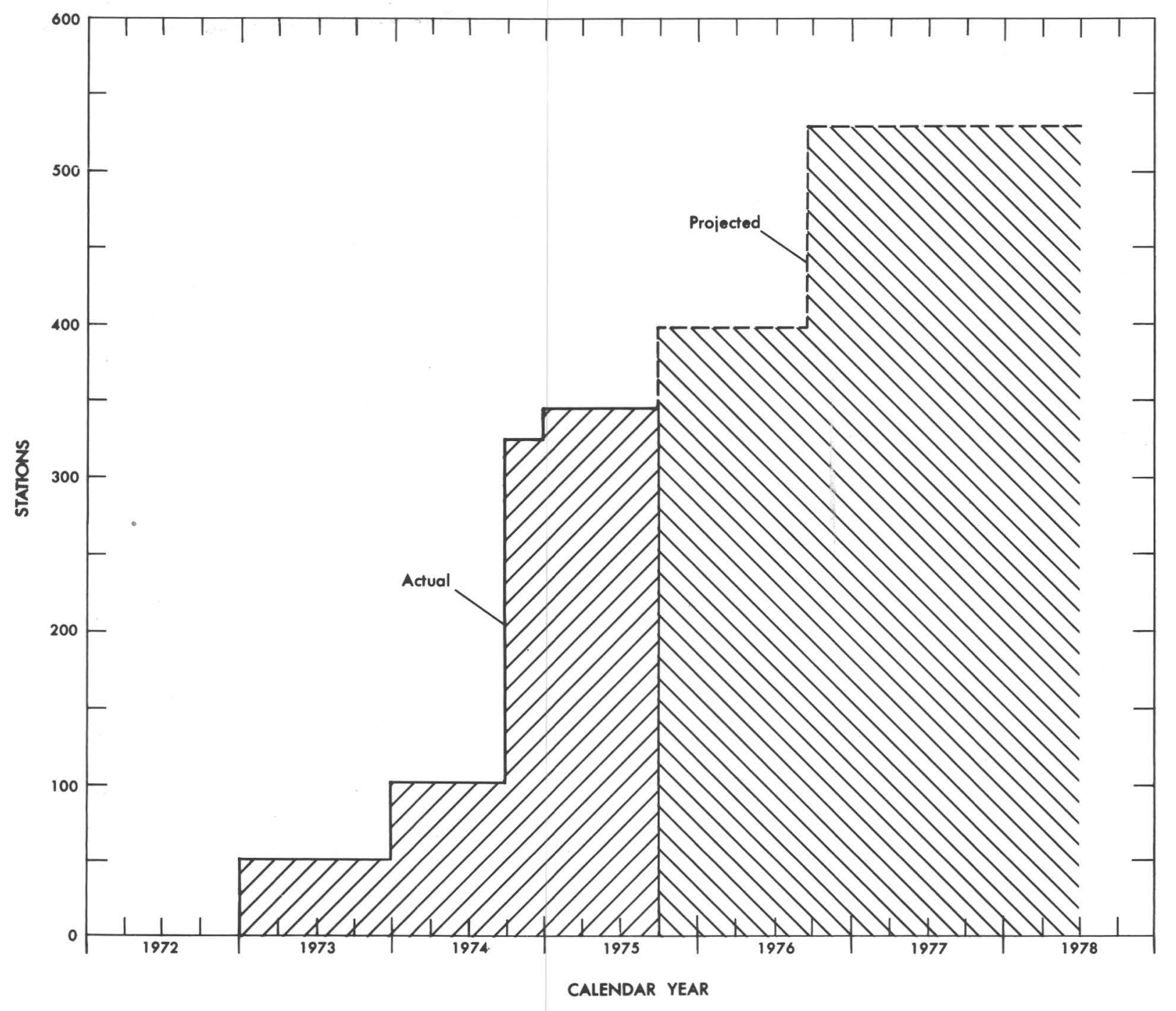

FIGURE 4.-Numbers of stations in the National Stream Quality Accounting Network, 1973-78.

some of the stations are operated partly by other Federal agencies, such as the Environmental Protection Agency and the U.S. Army Corps of Engineers, and some are operated partly by State and local organizations. For those stations operated by the Geological Survey, some are paid for partly by monies from other Federal agencies, from State and local cooperators, and from other more specialized Federal data-collection programs of the Geological Survey. Because of local interests or needs, it is not uncommon to have several different sources interested in and paying for total operations of a single station.

\section{How long will stations be operated?}

Indefinitely, as required by one of the network objectives-to assess changes in water quality with time. However, some changes in operating practices will be made, as explained previously in answer to a question regarding changes in the suite of characteristics. Such changes will be made only after it has been determined that the proposed modification, presumably a change in frequency of sampling, will not affect the fulfillment of network objectives. 


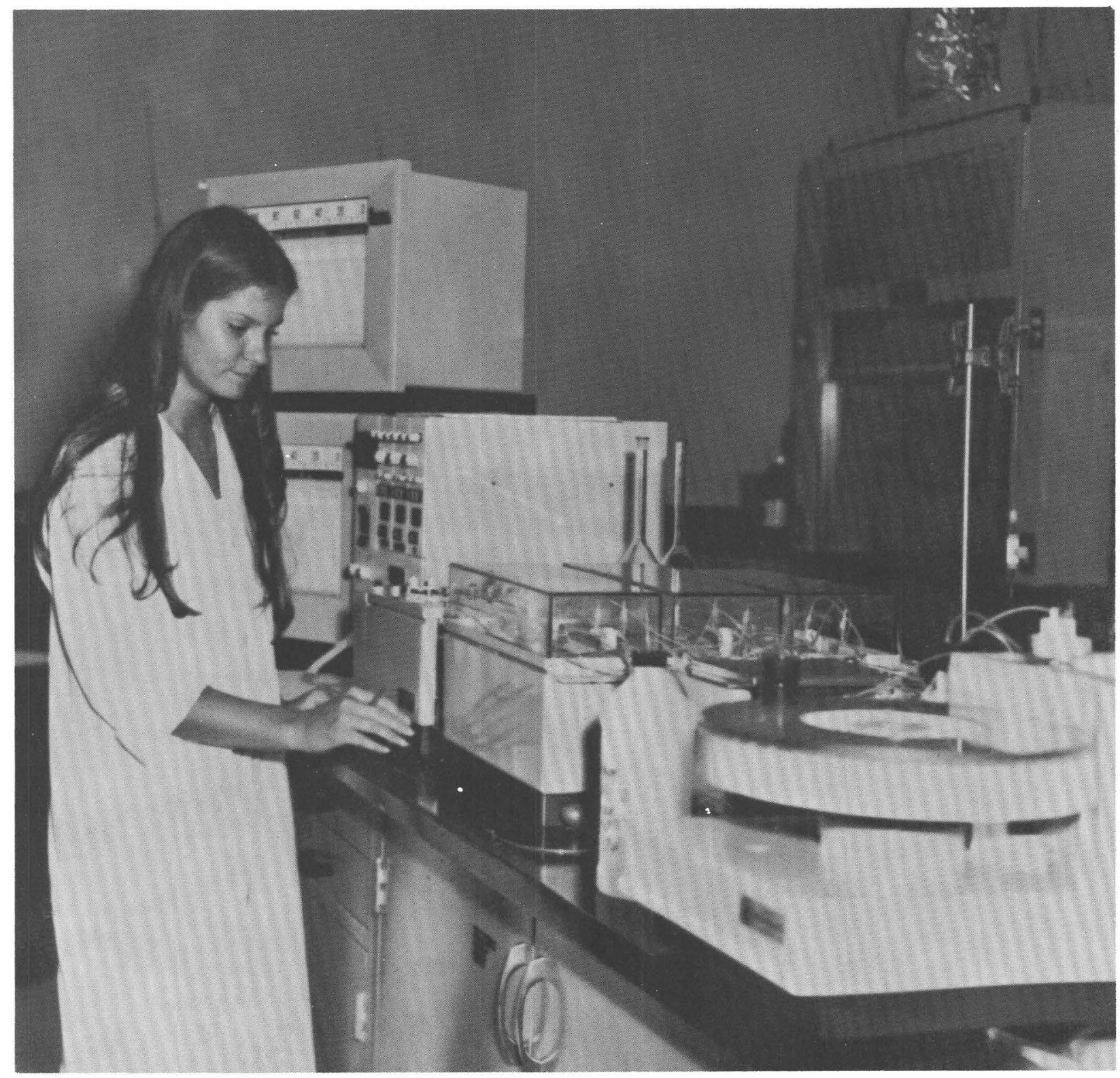

Automatic analyzer in Central Laboratory, Doraville, Ga.

\section{What will be done with the data?}

Present plans call for data collected under the auspices of NASQAN to be published in three types of publications.

First, all data will be published in the annual Geological Survey basic-data reports on a State-by-State basis. Copies of these reports can be obtained from Geological Survey district offices or from Geological Survey headquarters, Reston, Virginia 22092. Users of STORET, the computerized data base of the Environmental Protection Agency, can retrieve
NASQAN data by using Geological Survey station numbers (see table 1).

The second type of report is an annual summary report depicting the Nation's surfacewater quality. This report, the prototype of which should be completed by August 1975, will use tabulations of the yearly range in concentrations of specific constituents, statistical summaries, and graphical presentations.

The third type of report, which will be more analytical, will deal with the changes (or lack thereof) in water quality. Preliminary work by 
the Geological Survey (Steele and others, 1974) employed an approach which may be used to evaluate trends in water quality. This type of report will be prepared less frequently (every 3 to 5 years).

NASQAN interpretive reports (the second and third types) will be published in forms suitable for use by hydrologists as well as nontechnical persons.

\section{What will be the principal problems in the interpretation of the data?}

Undoubtedly there will be several problems in data interpretation, but two will probably be hardest to resolve: (1) Differentiating yearto-year variability (wet-year, dry-year effects) from the long-term trends and from the real areal differences in variables significantly affected by flow conditions, and (2) adjusting for the effects of streamflow regulation (particularly by reservoirs) or streamflow diversions on the water-quality conditions.

To resolve the first problem, several statistical and other analytical techniques are being evaluated to discover their utility in determining significant long-term trends from the data. For some water-quality characteristics, 5 or more years of data may be needed before adequate bases exist for detecting longterm trends.

Regarding the second problem, reservoirs are particularly significant because they alter the pattern of streamflow during the year and also influence many water-quality characteristics. Seasonal streamflow patterns are affected by patterns of reservoir release, but the annual volumes of flow usually do not change, except for evaporation losses. The quality of water released from reservoirs differs from that of inflow, in terms of temperature, dissolved solids, sediment, nutrients, dissolved oxygen, and other characteristics. There is much literature describing the processes that take place in reservoirs, but quantitative modeling is not far enough advanced to be helpful in determining the precise degree to which the reservoirs will affect water quality at NASQAN stations.

\section{What is the policy regarding NASQAN stations near reservoirs?}

The lower boundaries of many of the accounting units used to establish the hydrologic design of NASQAN cross stream channels at or just below dams. Because an objective of the network operation is to account for the quantity and quality of water actually flowing from one accounting unit into another, the placement of sampling stations below reservoirs is necessary. On the other hand, NASQAN's goal of interpreting changes in water quantity and quality in terms of cultural changes in the basin is not fully served by a station located below a reservoir because the effects of the reservoir will mask most other influences. Therefore, operation of NASQAN will involve evaluation of the effects of some reservoirs by placing secondary stations above several large reservoirs. These stations are referred to as secondary because they will be used to collect a more limited suite of data and probably will operate for a limited number of years.

\section{SUMMARY}

NASQAN is designed to describe the water quality of the Nation's streams and rivers on a systematic and continuing basis. NASQAN station operation supplements the ongoing activities of the U.S. Geological Survey and other agencies. Whereas other operations meet local and short-term needs, NASQAN provides for nationwide quantitative descriptions of the physical, chemical, and biological characteristics of streams. There presently are 345 stations in the network, and network design allows for an ultimate size of $\mathbf{5 2 5}$ stations.

\section{REFERENCES}

Enviro Control, 1972, National assessment of trends in water quality: U.S. Dept. Commerce, Natl. Tech. Inf. Service, $\mathrm{PB}-210669,52 \mathrm{p}$.

Langford, R. H., and Davis, G. H., 1970, National system for water data: Am. Soc. Civil Engineers Proc., Jour. Hydraulics Div., v. 96, no. HY7, p. 1391-1401.

Steele, T. D., Gilroy, E. J., and Hawkinson, R. O., 1974, An assessment of areal and temporal variations in streamflow quality using selected data from the National Stream Quality Accounting Network: U.S. Geol. Survey open-file rept. 74-217, 210 p.

Water Resources Council, 1970, Water resources regions and subregions for the national assessment of water and related land resources: Washington, D.C., U.S. Water Resources Council, 188 p., 6 plates.

Wolman, M. G., 1971, The Nation's rivers: Science, v. 174, no. 4012, p. $905-918$. 
TABLE 1 
TABLE 1.-Stations in the National Stream Quality Accounting Network on January 1, 1975

\begin{abstract}
USGS
STAT.NO.
\end{abstract}

STATION NAME

\section{$S T^{1}$ LATI - LONGI - \\ TUDE TUDE \\ DEG/ DEG/ \\ MIN MIN}

02420000 ALABAMA RIVER NEAR MONTGOMERY

02429500 ALABAMA RIVER AT CLAIBORNE

02449000 TOMBIGBEE RIVER AT GAINESVILLE

02469762

15024800 15294350 15304000 15565447 15744500 15896000

09380000 09401200 09421500 09426600 09429490 09466500 09473500 09474000 09489000 09502000 09510000 09518000 09520700 09522000

07032000 07047800 07047900 07077800 07250550 07263620 07265450 07362000

09424190 10254970 10277400 10261500 11074000 11103010 11152500 11250000 11303500

MISSISSIPPI RIVER AT MEMPHIS

ST FRANCIS RIVER NEAR PARKIN

WHITE RIVER AT CLARENDON

OUACHITA RIVER AT CAMDEN

SALINAS RIVER NEAR SPRECKELS

FRAINT-KERN CANAL AT FRAINT
TOMBIGBEE R. AT COFFEEVILLE L\&D

STIKINE RIVER NEAR WRANGELL SUSITNA RIVER AT SUSITNA STATION KUSKOKWIM RIVER AT CROOKED CREEK YUKON RIVER AT PILOT STATION KOBUK RIVER NEAR KIANA KUPARUK RIVER NEAR DEADHORSE

COLORADO RIVER AT LEES FERRY LITTLE COLORADO RIVER AT CAMERON COLORADO RIVER BELOW HOOVER DAM BILL WILLIAMS R BL MINERAL WASH NR PLANETAZ 3416 COLORADO RIVER ABOVE IMPERIAL DAM GILA RIVER AT CALVA SAN PEDRO RIVER AT WINKELMAN GILA RIVER AT KELVIN SANTA CRUZ RIVER NEAR LAVEEN SALT RIVER BELOW STEWART MT DAM VERDE RIVER BELOW BARTLETT DAM GILA RIVER ABOVE DIV AT GILLESPIE DAM GILA RIVER NEAR MOUTH NEAR YUMA COLORADO RIVER AT N.INT.BURY.AB MORELOS

AK 5642

AK 6132

AK 6152

AK 6156

AK 6658

AK 7017

$A 23311$

AZ 3259

AZ 3306

AZ 3314

AZ 3334

AZ 3349

AZ 3243

DAZ 3243
AL $3224 \quad 08624$

AL $3133 \quad 08731$

AL 324908809

08808

13207

15033

15807

16253

16007

14858

$A Z \quad 3652 \quad 11135$

AZ $3553 \quad 11125$

AZ $3601 \quad 11444$

$A Z 3253 \quad 11428$

AZ 3314

(TN) AR 3508

AR 3516

AR 3516

AR 3441

AR 3521

AR 3440

AR 3334

AR 3336

11031

11049

11059

11210

11132

11138

11246

11433

11443

ARKANSAS RIVER AT DAM 13 NEAR VAN BUREN

ARKANSAS RIVER AT L AND D 6 LIT ROCK

MISSISSIPPI RIVER NEAR ARKANSAS CITY

CA 3349

11658

CA 3240

11530

NEW RIVER AT INT. BDRY. NR. CALEXICO

CA 3703

CA 3434

11813

OWENS RIVER BLW TINEMAHA D. NR BIG PINE

MOJAVE R. AT LOW NARROWS NR VICTORVILLE

SANTA ANA RIVER BELOW PRADO DAM

CA 3353

11719

LOS ANGELES K.AT WIL.ST.BRDG.AT LONG BCH

CA 3348

11739

11812

CA 3638

12140

CA 3700

11942

CA 3741

12116 
TABLE 1.-Stations in the National Stream Quality Accounting Network on January 1, 1975-Continued
USGS
STAT.NO.
STATION NAME

11325500 MOKELUMNE RIVER AT WOODBRIUGE

11447650 SACRAMENTO RIVER AT FREEPORT

11467000 RUSSIAN RIVER NEAR GUERNEVILLE

11530500 KLAMATH RIVER NEAR KLAMATH

06764000 SOUTH PLATTE RIVER AT JULESBURG

07137500 ARKANSAS RIVER NR COOLIDGE

08251500 RIO GRANDE NEAR LOBATOS

09152500 GUNNISON RIVER NEAR GRAND JUNCTION

09163530 COLORADO RIVER BLW. COLO-UTAH STATE

09251000 YAMPA RIVER IVEAR MAYBELL

092600.00 LITTLE SNAKE RIVER NEAR LILY

01184000 CONNECTICUT RIVER AT THOMPSONVILLE
01205500 HOUSATONIC RIVER AT STEVENSON
$S T^{1}$ LATI- LONGI-
TUCE TUDE
DEG/ DEG/
MIN'

CA $3810 \quad 12118$

CA $3827 \quad 12130$

CA $38: 0 \quad 12256$

CA $4121 \quad 12358$

CO $4059 \quad 10215$

(KS) CO $38 r_{2} 10201$

CO $37 C 5 \quad 10545$

CO 38:9 10827

CO $39 r 510906$

CO $4050 \quad 10802$

CO $40: 3 \quad 10825$

CT 4159 07236

CT 412307310

FL 302208205

FL 292908138

FL 291308103

FL 273908024

FL $2714 \quad 08058$

FL $26: 908004$

FL $2548 \quad 08016$

MIAMI CANAL AT NW 36TH STREET, MIAMI FL 2548

CALOOSAHATCHEE CNL AT ORTONA L.NR LABELLEFL 2650

08105

FL $2713 \quad 08153$

FL 281908214

FL 285908221

FL $2957 \quad 08256$

FL $30: 3 \quad 08423$

FL $3042 \quad 08452$

FL $30: 2 \quad 08510$

FL $3027 \quad 08554$

FL 304508638

FL $3057 \quad 08714$

GA 3211 08125

GA $31: 908149$

GA 311308152

HI 2159 15940

HI 2123 15801

HI $2120 \quad 15753$

HI $2110 \quad 15646$

HI 205915633

HI 194315509 
TABLE 1.-Stations in the National Stream Quality Accounting Network on January 1, 1975-Continued

USGS

STAT.NO.

12318500 KOOTENAI RIVER NEAR COPELAND

13154500 SNAKE RIVER AT KING HILL

13213000 BOISE RIVER NEAR PARMA

13213100 SNAKE RIVER AT NYSSA

13290450 SNAKE RIVER AT HELLS CANYUN DAM

13317000 SALMON RIVER AT WHITE BIRD

05446500 ROCK RIVER NEAR JOSLIN

05543500 ILLINOIS RIVER AT MARSEILLES

05585500 ILLINOIS RIVER AT MEREDOSIA

05594100 KASKASKIA RIVER NEAR VENDY STATION

05599500 BIG MUDDY RIVER AT MURPHYSHORO

03276500 WHITEWATER RIVER AT BROOKVILLE

03374100 WHITE RIVER NEAR HAZELTON

03378500 WABASH RIVER AT NEW HARMONY

05420500 MISSISSIPPI KIVER AT CLINTON

05474500 MISSISSIPPI HIVER AT KEOKUK

06486000 MISSUURI RIVEK AT SIUUX CITY

06807000 MISSOURI KIVER AT NEBRASKA CITY

06856600 REPUBLICAN RIVER AT CLAY CENTER

06877600 SMOKY HILL RIVER AT ENTERPRISE

06887000 BIG BLUE RIVER NEAR MANHATTAN

06892350 KANSAS RIVER AT DESOTO

07139500 ARKANSAS RIVER AT DODGE CITY

07146500 ARKANSAS RIVER AT ARKANSAS CITY

03215000 BIG SANDY RIVER AT LOUISA

03216600 OHIO RIVER AT GREENUP DAM

03254000 LICKING RIVER AT BUTLER

03277200 OHIO R. AT MARKLAND DAM NEAR WARSAW

03290500 KENTUCKY RIVER AT LOCK 2 AT LOCKPORT

03301630 ROLLING FORK NEAR LEHANON JUNCTION

03303280 OHIO RIVER AT CANNELTON DAM

03321230 GREEN RIVER NEAR BEECH GROVE

03438220 CUMBERLAND RIVER NEAR GRAND RIVERS

03609750 TENNESSEE RIVER AT HWY 60 NEAR PADUCAH

03612500 OHIO RIVER AT LGD 53 NEAR GRAND CHAIN(IL)

02489500 PEARL RIVER NEAR BOGALUSA

02492000 BOQUE CHITTO NEAR BUSH

07344410 RED RIVER ABOVE SHREVEPORT

07355500 RED RIVER AT ALEXANDRIA

07367640 OUACHITA RIVER AT COLUMBIA

1 See footnote at end of table.

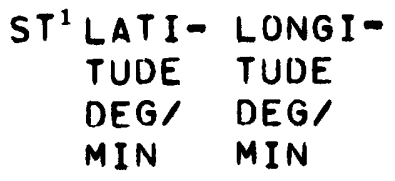

$\begin{array}{llll} & \text { ID } & 4855 & 11625 \\ & \text { ID } & 4300 & 11512 \\ \text { ID } & 4347 & 11659 \\ \text { (OR) } & \text { ID } & 4353 & 11659 \\ \text { (OR) } & \text { ID } & 4515 & 11642 \\ & \text { ID } & 4545 & 11619\end{array}$

IL 414309011

IL $4120 \quad 08843$

IL $3949 \quad 09034$

IL $3827 \quad 08938$

IL $3745 \quad 08921$

IN $3924 \quad 08501$

IN 382908733

IN $3808 \quad 08756$

IA $4147 \quad 09015$

IA 402409122

IA 422909625

(NB) IA 404109551

KS 392109708

KS $3854 \quad 09707$

KS 3914 09634

KS 385909458

KS 374510001

KS $3703 \quad 09704$

KY $3810 \quad 08238$

KY 383908252

KY $3847 \quad 08422$

KY $3846 \quad 08458$

KY $3826 \quad 08458$

KY $3749 \quad 08545$

KY 3754 08642

KY $3732 \quad 08716$

KY 3701 08813

KY $3702 \quad 08832$

08902

LA $3048 \quad 08949$

LA 303808954

LA 323309346

LA 311909227

LA $3206 \quad 09204$ 
TABLE 1.-Stations in the National Stream Quality Accounting Network on January 1, 1975-Continued
USGS
STATION NAME
STAT.NO.

07369500 TENSAS RIVEK AT TEMDAL

07373420 MISSISSIPPI RIVER NEAR ST FRANCISVILLE

07374508 MISSISSIPPI RIVEK AT NEW ORLEANS

07378510 AMITE RIVER AT 4-H CAMP NR DENHAM SPGS

07381490

ATCHAFALAYA RIVER AT SIMMESPORT

07385700

BAYOU TECHE AT KEYST

L\&D NR ST MA

08015900

CALCASIEU RIVER NEAR

LAKE CHARLES

01017100

01021050

ARUOSTUOK RIVER AT CARIBOU

01034500

01046500

ST. CROIX RIVER AT MILLTOWN

01059000

PENOBSCOT RIVER AT WEST ENFIELD

01066000

KENNEREC RIVER AT BINGHAM

ANDROSCOGGIN RIVER NEAR AUBURN

01491000 CHOPTANK RIVER NEAR GREENSBORO

01645500 POTOMAC RIVER AT GREAT FALLS

O 1096550 MERRIMACK RIVER ABOVE LOWELL

01103500 CHARLES RIVER AT CHARLES RIVER VILLAGE

04040000 ONTONAGON RIVER NEAR ROCKLAND

04045500 TAHQUAMENON $K$. NR TAHQUAMENON PARADISE

04045580 ST MARYS RIVER ABOVE SAULT STE MARIE

04057005 MANISTIQUE RIVER AT MANISTIQUE

04059000 ESCANABA RIVER AT CORNELL

04059500 FORD RIVER NEAR HYDE

04108690 KALAMAZOO RIVER AT SAUGATUCK

04122030 MUSKEGON RIVER AT BRIDGETON

04126520 MANISTEE RIVER AT MANISTEE

04132052 CHEBOYGAN RIVER AT CHEBUYGAN

04142000 RIFLE RIVER NEAR STERLING

04157000 SAGINAW RIVEK AT SAGINAW

04165500 CLINTON RIVER AT MT. CLEMENS

04165700 DETRUIT RIVER AT DETROIT

04014500 BAPTISM RIVER NEAR BEAVER BAY

04024000 ST LOUIS RIVER AT SCANLON

05112000 ROSEAU RIVER NEAR CARIBOU

05131500 LITTLE FORK RIVER AT LITTLEFORK

05132000 BIG FORK RIVER AT BIG FALLS

05267000 MISSISSIPPI RIVER NEAR ROYALTON

05331000 MISSISSIPPI RIVER AT ST PAUL

05378500 MISSISSIPPI RIVER AT WINONA

05533000 MINNESOTA RIVER NEAR JORDAN
$S T^{1}$ LATI - LONGI - TUDE TUDE
$D E G / D E G /$
MIN MIN

LA $3226 \quad 09122$

LA $3046 \quad 09124$

LA $2957 \quad 09008$

LA $3026 \quad 09058$

LA 305909148

LA $3004 \quad 09150$

LA 301809311

ME 465106800

ME $4510 \quad 06718$

ME $4514 \quad 06839$

ME $4503 \quad 06953$

ME $4404 \quad 07013$

ME $4348 \quad 07047$

MD $3900 \quad 07547$

MD $3900 \quad 07715$

MA $4238 \quad 07122$

MA $4215 \quad 07116$

MI $4643 \quad 08912$

MI $4643 \quad 08516$

MI 462908425

MI $4557 \quad 08615$

MI $4555 \quad 08713$

MI $4545 \quad 08712$

MI 423908612

MI 431908602

MI 441508619

MI 453908428

MI $4404 \quad 08401$

MI $4325 \quad 08358$

MI $4236 \quad 08255$

MI 4221 08258

MN $4720 \quad 09112$

MN $4642 \quad 09225$

MN 485909628

MN 482409334

MN 4812 09348

MN $4552 \quad 09422$

MN $4457 \quad 09305$

MN $4403 \quad 09138$

MN $4442 \quad 09338$

1 See footnote at end of table. 
TABLE 1.-Stations in the National Stream Quality Accounting Network on January 1, 1975-Continued

USGS
STAT.NO.

02479020 PASCAGOULA RIVER NEAR BENNDALE

07287000 YAZOO RIVER AT GREENWOOD

07289000 MISSISSIPPI RIVER AT VICKSBURG

07290000 BIG BLACK RIVER NEAR ROVINA

07292500 HOMOCHITTO RIVER AT ROSETTA

05490600 DES MOINES RIVER AT ST FRANCISVILLE

05587550 MISSISSIPPI RIVER RELOW ALTON

06818000 MISSOURI RIVER AT ST JOSEPH

06902000 GRAND RIVER NEAR SUMNER

06926500 OSAGE RIVER NEAR ST. THOMAS

06934500 MISSOURI RIVER AT HERMAN

07022000 MISSISSIPPI RIVER AT THEBES

06054500 MISSOURI RIVER AT TOSTON

06109500 MISSOURI RIVER AT VIRGELLE

06130500 MUSSELSHELL RIVER AT MOSBY

06132000 MISSOURI RIVER BELOW FT PECK DAM

06174500 MILK RIVER AI NASHUA

06185500 MISSOURI RIVER NEAR CULBERTSON

06214500 YELLOWSTONE RIVER AT BILLINGS

06294700 BIGHORN RIVER AT BIGHORN

06308500 TONGUE RIVER AT MILES CITY

06326500 POWDER RIVER NEAR LOCATE

06329500 YELLOWSTONE RIVER NEAR SIDNEY

12355000 N.F. FLATHEAD RIVER AT FLATHEAD, B.C.

06465500 NIOBRARA RIVER NEAR VERDEL

06686000 NORTH PLATTE RIVER AT LISCU

06792499 LOUP RIVER ON AT DIV NR GENOA

06796000 PLATTE RIVER AT NORTH BEND

06805500 PLATTE RIVER NEAR LOUISVILLE

10249900 CHIATOVICH CREEK NEAR DYER

10301500 WALKER RIVER NEAR WABUSKA

10312000 CARSON RIVER NEAR FORT CHURCHILL

10335000 HUMBOLDT RIVER NEAR RYE PATCH

10346000 TRUCKEE RIVER AT FARAD

10351700 TRUCKEE RIVER NEAR NIXON

10352500 MC DERMITT CREEK NEAR MC DERMITT

\section{CONNECTICUT RIVER AT NORTH WALPOLE}

01404100 RARITAN RIVER NEAR SOUTH BOUND BROOK

01408500 TOMS RIVER NEAR TOMS RIVER

01463500 DELAWARE RIVER AT TRENTON

${ }^{1}$ See footnote at end of table.
ST'LATI - LONGI-
TUDE TUDE
DEG/ DEG/
MIN MIN

MS $3053 \quad C 8846$

MS $3331 \quad 19011$

MS $3219 \quad 09054$

MS $3221 \quad(9042$

MS $3119 \quad 09106$

MO $4028 \quad 99134$

(IL) MO $3852 \quad 19008$

MO $3948 \quad r 9453$

MO $3938 \quad(9316$

MO $3820 \quad 19214$

MO $3843 \quad r 9126$

(IL) MO $3713 \quad 08928$

MT $4609 \quad 11125$

MT $4800 \quad 11015$

MT $4700 \quad 10753$

MT $4803 \quad 10621$

MT $4808 \quad 10622$

MT $4807 \quad 10428$

MT $4548 \quad 10828$

MT $4069 \quad 10728$

MT $4622 \quad 10548$

MT $4627 \quad 10519$

MT $4741 \quad 10409$

MT $4900 \quad 11428$

NB $4244 \quad 09813$

NB $4130 \quad 10238$

NB $4124 \quad 09749$

NB $4127 \quad 09646$

NB 410109609

NV $3750 \quad 11812$

NV $3909 \quad 11906$

NV $3918 \quad 11919$

NV $4028 \quad 11818$

(CA) NV $3926 \quad 12002$

NV $3947 \quad 11920$

NV $4158 \quad 11750$

NH $4308 \quad 07226$

NJ 403107432

NJ 395907413

NJ 401307447 
TABLE 1.-Stations in the National Stream Quality Accounting Network on January 1, 1975--Continued
USGS
STATION NAME
STAT.NO.

07227140 08313000 08358300 08407500 08481500 09368000

01304500 01372043 04219640 04232006 04249000 04260500 04264331 04269000 04295000

02081000 02083500 02089500 02105769 02129000

05054020 05083500 05124000 06337000 06338490 06340500 06354000

03150000 03234500 03245500 03274600 04193500 04208000

07157950 07161000 07164400 07178620 07193500 07231500 07232500 07234000 PECOS RIVER AT RED BLUFF TULAROSA RIVER NEAR BENT BLACK RIVER AT WATERTOWN TAR RIVER AT TARBORO NEUSE RIVER AT KINSTON KNIFE RIVER AT HAZEN CANNON RIVER NEAR BREIEN SCIOTO RIVEH AT HIGEY CANADIAN RIVER AT CALVIN
CANADIAN RIVER aBOVE NM-TEX STATELINE RIO GRANDE AT OTOWI BRIDGE NR S.ILDEFONSONM RIO GRANDE CNV CH AT SAN MARCIAL SAN JUAN RIVER AT SHIPROCK

\section{PECONIC RIVER AT RIVERHEAD} HUDSON RIVER NEAR POUGHKEEPSIE NIAGARA RIVER AT FORT NIAGARA GENESEE R AT CHARLOTTE DOCKS AT OSWEGO RIVER AT LOCK 7, OSWEGO ST LAWRENCE R AT CORNWALL ONT NR MASSENA ST REGIS RIVER AT BRASHER CENTER RICHELIEU RIVER AT ROUSES POINT

ROANOKE RIVER NEAR SCOTLANO NECK CAPE FEAR RIVER AT LOCK I NEAR KELLY PEE DEE RIVEH NEAR ROCKINGHAM

RED RIVER OF THE NORTH BELOW FARGO RED RIVER OF THE NORTH AT OSLO SOURIS RIVER NEAR WESTHOPE (OUTFLOW) (MN) LITTLE MISSOURI RIVER NEAK WATFORO CITY MISSOURI RIVER AT GARRISON DAM

MUSKINOUN RIVER AT MCCONNELSVILLE LITTLE MIAMI RIVER AT MILFURD GREAT MIAMI RIVER AT NEW BALTIMORE MAUMEE RIVER AT WATERVILLE CUYAHOGA RIVER AT INDEPENOENCE

CIMARRON RIVER NEAR BUFFALU CIMARRON RIVER AT PERKINS ARKANSAS RIVER AT SD SPNG NEAR TUL NEWT GRAHAM LGD (VERDIGRIS R) NEAR INOLA NEOSHO R BL FT GIBSON RES NR FT GIBSON N CANADIAN RIVER NEAR GUYMON

${ }^{1}$ See footnote at end of table.

$$
\begin{gathered}
S T^{1} \text { LATI- LONGI- } \\
\text { TUDE TUDE } \\
\text { DEG/ DEG/ }
\end{gathered}
$$

NM 3523

10303

NM 3341

10608

10700

NM 3204

NM 3309

10402

10554

NM 3648 10844

NY $4100 \quad 07241$

NY $4143 \quad 07356$

NY $4316 \quad 07904$

07737

NY 432707630

NY 435907556

NY $4500 \quad 07448$

NY $4452 \quad 07447$

NY $4500 \quad 07322$

NC 361207723

NC $3554 \quad 07732$

NC 351507735

NC 3424 07818

NC $3457 \quad 07952$

ND $4656 \quad 09647$

ND 481209708

ND $4900 \quad 10057$

NO 473510315

ND $4730 \quad 10126$

ND $4717 \quad 10137$

ND 462310056

OH 393908151

OH $3913 \quad 08252$

OH $3910 \quad 08418$

OH 391608440

$\mathrm{OH} 4130 \quad 08343$

OH 4124 08138

OK $3655 \quad 09924$

OK 3559 09702

OK $3607 \quad 09607$

OK $3603 \quad 09532$

OK 355109514

OK 345909614

OK 364310130

OK $3649 \quad 10031$ 
TABLE 1.-Stations in the National Stream Quality Accounting Network on January 1, 1975-Continued

USGS

STAT •NO.

07237500 NORTH CANADIAN RIVER AT WUUDWARD

07245000 CANADIAN RIVEK NEAR WHITEFIELD

07305000 NF RED RIVER NEAR HEADRICK

07331000 WASHITA RIVEK NEAR DURWOOU

10396000 DONNER UND BLITZEN R. NEAR FRENCHGLEN

14048000 JOHN DAY RIVER AT MCDONALU FERRY

14103000 DESCHUTES RIVER AT MOODY NEAR RIGGS

14128910 COLUMBIA RIVER AT WARRENDALE

14207500 TUALATIN RIVER AT WEST LINN

14211720 WILLAMETTE RIVER AT PORTLAND

14301000 NEHALEM RIVER NEAR FOSS

14321000 UMPQUA RIVER NEAR ELKTON

14372300 RUGUE RIVER NEAR AGNESS

01474500 SCHUYLKILL RIVER AT PHILADELPHIA

01540500 SUSQUEHANNA RIVER AT DANVILLE

$01553500 \mathrm{~W} \cdot B R$. SUSOUEHANNA RIVER AT LEWISBURG

01570500 SUSOUEHANNA RIVER AT HARRISBURG

03049625 ALLEGHENY RIVER AT NEW KENSINGTON

03085000 MONONGAHELA KIVER AT BRADUOCK

50038100 RIO GRANDE DE MANATI

50046000 RIO DE LA PLATA AT TOA ALTA

50092000 RIO GRANDE DE PATILLAS NEAR PATILLAS

50144000 RIO GRANDE DE ANASCO NEAR SAN SEBASTIAN

02132000 LYNCHES RIVER AT EFFINGHAM

02136000 BLACK RIVER AT KINGSTREE

02170500 LAKE MARION MOULTRIE CANAL NR PINEVILLE

02171500 SANTEE RIVER NEAR PINEVILLE

02175000 EDISIO RIVER NEAR GIVHANS

02176500 COOSAWHATCHIE RIVER NEAR HAMPTON

02198500 SAVANNAH RIVER NEAR CLYO

06357800 GRAND RIVER AT LITTLE EAGLE

06438000 BELLE FOURCHE RIVER NEAR ELM SPRINGS

06439300 CHEYENNE RIVER AT CHERRY CREEK

06440000 MISSOURI RIVER AT PIERRE

06452000 WHITE RIVER NEAR OACOMA

06453000 MISSOURI RIVER BELOW FT RANDALL DAM

06478500 JAMES RIVER NEAR SCOTLAND

06485500 BIG SIOUX RIVER AT AKRON

\section{CUMBERLAND KIVER AT CARTHAGE}

03470500 FRENCH BROAD RIVER NEAR KNOXVILLE

1 See footnote at end of table.
(GA)

ST'LATI- L.ONGI-
TUDE TUOE
DEG/ CEG/
MIN MIN

OK $3626 \quad 09917$

OK $3516 \quad 09514$

OK $3438 \quad 09906$

OK 341409659

OR $4247 \quad 11852$

OR $4535 \quad 12024$

OR $4537 \quad 12054$

OR $4537 \quad 12202$

OR $4521 \quad 12240$

OR $4531 \quad 12240$

OR $4542 \quad 12345$

OR $4335 \quad 12333$

OR $4235 \quad 12404$

PA $4000 \quad 07512$

PA $4057 \quad 07637$

PA $4058 \quad 07653$

PA 401507653

PA 403407946

PA 402407953

PR $1826 \quad 06632$

PR $1824 \quad 06615$

PR $1802 \quad 06602$

PR 181706703

SC 340307945

SC $3340 \quad 07950$

SC 332308008

SC 332708009

SC 330208024

SC $3250 \quad 08108$

SC 323208116

SD $4530 \quad 10049$

SD $4422 \quad 10234$

SD 443610129

SD $4422 \quad 10022$

SD $4345 \quad C 9933$

SD $4304 \quad 09833$

SD $4311 \quad 09738$

(IA) SD $4250 \quad 09634$

TN $3615 \quad 08557$

TN $3558 \quad 08346$ 
TABLE 1.-Stations in the National Stream Quality Accounting Network on January 1, 1975--Continued

USGS STATION NAME
STAT.NO.
$S T^{1}$ LATI - LONGI-
TUDE TUDE
DEG/ DEG/
MIN MIN

\begin{tabular}{|c|c|c|c|}
\hline & $\begin{array}{l}\text { NESSEE R. AT WATTS BAR UAM ITAILWATER } \\
\text { NESSEE RIVER AT SOUTH PITTSBURG } \\
\text { NESSEE R. AT PICKWICK LAND. D. LL.LOCK } \\
\text { ON RIVEH AT OBION }\end{array}$ & TN & \\
\hline & $\begin{array}{l}\text { CANADIAN RIVER NEAR CANADIAN } \\
\text { PDTF RED RIVER NEAR WAYSIDE TEXAS } \\
\text { SALT FORK RED RIVER NEAR WELLINGTON } \\
\text { RED RIVER NEAR BURKBURNETT } \\
\text { RED RIVER AT DENISON DAM NEAR DENISON } \\
\text { SABINE RIVER NEAR RULIFF } \\
\text { NECHES RIVER AT EVADALE } \\
\text { TRINITY RIVER NEAR CROCKETT } \\
\text { TRINITY RIVER AT ROMAYOR } \\
\text { WEST FORK SAN JACINTO RIVER NEAR CONF } \\
\text { SALT FORK BRAZOS RIVER NEAR ASPERMONI } \\
\text { BRAZOS RIVER AT SEYMOUR } \\
\text { BRAZOS RIVER NEAR HIGHBANK } \\
\text { BRAZOS RIVER AT ROSHARON } \\
\text { BEALS CREEK NEAR WESTBROOK } \\
\text { COLORADO RIVER NEAR STACY } \\
\text { COLORADO RIVER AT AUSTIN } \\
\text { COLORADO RIVER AT WHARTON } \\
\text { NAVIDAD RIVER NEAR GANADO } \\
\text { GUADALUPE RIVER AT VICTORIA } \\
\text { SAN ANTONIO HIVER AT GOLIAD } \\
\text { NUECES RIVER NEAR THREE RIVERS } \\
\text { LOS OLMOS CREEK NEAR FALFUNRIAS } \\
\text { RIO GRANDE AT FT OUITMAN } \\
\text { RIO GRANDE AT FOSTER RANCH } \\
\text { PECOS RIVER NEAR LANGTRY } \\
\text { RIO GRANDE AT LAREDO } \\
\text { RIO GRANDE AT BROWNSVILLE }\end{array}$ & $\begin{array}{l}T X \\
T X \\
T X \\
T X \\
T X \\
T X \\
T X \\
T X \\
T X \\
T X \\
T X \\
T X \\
T X \\
T X \\
T X \\
T X \\
T X \\
T X \\
T X \\
T X \\
T X \\
T X \\
T X \\
T X \\
T X \\
T x\end{array}$ & \\
\hline & $\begin{array}{l}\text { COLORADO RIVER NEAR CISCO } \\
\text { GREEN RIVER NEAR GREENDALE } \\
\text { GREEN RIVER AT GREEN RIVER } \\
\text { SAN JUAN RIVER NEAR BLUFF } \\
\text { BEAR LAKE OUTLET CANAL NEAR PARI } \\
\text { BEAR RIVER NEAR CORINNE } \\
\text { WEBER RIVER NEAR PLAIN CITY } \\
\text { JORDAN RIVER AT SALT LAKE CITY } \\
\text { SEVIER RIVER NEAR LYNNDYL } \\
\text { BEAVER RIVER AT ADAMSVILLE }\end{array}$ & $\begin{array}{l}\text { UT } \\
\text { UT } \\
\text { UT } \\
\text { UT } \\
\text { UT } \\
\text { UT } \\
\text { UT }\end{array}$ & \\
\hline & -YDE RIVER AT NEWPORT & 1 & \\
\hline
\end{tabular}


TABLE 1.-Stations in the National Stream Quality Accounting Network on January 1, 1975-Continued

\begin{tabular}{|c|c|c|c|c|}
\hline $\begin{array}{l}\text { USGS } \\
\text { STAT.NO. }\end{array}$ & STATION NAME & & $\begin{array}{l}\text { LATI- } \\
\text { TUDE } \\
\text { DEG/ }\end{array}$ & $\begin{array}{l}\text { LONG I- } \\
\text { TUUE } \\
\text { DEG/ }\end{array}$ \\
\hline $\begin{array}{l}01673000 \\
02035000 \\
02049500\end{array}$ & $\begin{array}{l}\text { PAMUNKEY RIVER NEAR HANOVER } \\
\text { JAMES RIVER AT CARTERSVILLE } \\
\text { BLACKWATER RIVER NEAR FRANKLIN }\end{array}$ & $\begin{array}{l}\text { VA } \\
\text { VA } \\
\text { VA }\end{array}$ & $\begin{array}{l}3746 \\
3740 \\
3646\end{array}$ & $\begin{array}{l}07720 \\
07805 \\
07654\end{array}$ \\
\hline $\begin{array}{l}12031000 \\
12045500 \\
12200500 \\
12398600 \\
12400520 \\
12433000 \\
12510500 \\
13353200 \\
14113000\end{array}$ & $\begin{array}{l}\text { CHEHALIS RIVER AT PORTER } \\
\text { ELWHA R AT MCDONALD BRIDGE NR PT ANGELES } \\
\text { SKAGIT RIVER NEAR MT VERNUN } \\
\text { PEND OREILLE R AT INTERNATIONAL BOUNDARY } \\
\text { COLUMBIA RIVER AT NORTHPORT } \\
\text { SPUKANE RIVER AT LONG LAKE } \\
\text { YAKIMA RIVER AT KIONA } \\
\text { SNAKE RIVER AT BURBANK } \\
\text { KLICKITAT RIVER NEAR PITT }\end{array}$ & $\begin{array}{l}\text { WA } \\
\text { WA } \\
\text { WA } \\
\text { WA } \\
\text { WA } \\
\text { WA } \\
\text { WA } \\
\text { WA } \\
\text { WA }\end{array}$ & $\begin{array}{l}4656 \\
4803 \\
4831 \\
4900 \\
4855 \\
4750 \\
4615 \\
4613 \\
4545\end{array}$ & $\begin{array}{l}12319 \\
12335 \\
12220 \\
11721 \\
11747 \\
11751 \\
11929 \\
11901 \\
12113\end{array}$ \\
\hline $\begin{array}{l}03201300 \\
03204500\end{array}$ & $\begin{array}{l}\text { KANAWHA RIVER AT .WINFIELO } \\
\text { MUD RIVER NEAR MILTON }\end{array}$ & $\begin{array}{l}\text { WV } \\
\text { WV }\end{array}$ & & \\
\hline $\begin{array}{l}04027000 \\
04085000 \\
04087000 \\
05340500 \\
05369500 \\
05407000\end{array}$ & $\begin{array}{l}\text { BAD RIVER NEAR ODANAH } \\
\text { FOX RIVER AT WRIGHTSTOWN } \\
\text { MILWAUKEE RIVER AT MILWAUKEE } \\
\text { ST CROIX RIVER AT ST. CROIX FALLS } \\
\text { CHIPPEWA RIVER AT DURAND } \\
\text { WISCONSIN RIVER AT MUSCODA }\end{array}$ & $\begin{array}{l}W I \\
W I \\
W I \\
W I \\
W I \\
W I\end{array}$ & $\begin{array}{l}4629 \\
4420 \\
4306 \\
4524 \\
4438 \\
4312\end{array}$ & $\begin{array}{l}09042 \\
08810 \\
08755 \\
09239 \\
09158 \\
09026\end{array}$ \\
\hline 302 & I VER & $W Y$ & 318 & 11047 \\
\hline
\end{tabular}


. 